\title{
Resistant pediatric priapism: A real challenge for the urologist
}

\author{
Cagri Akin Sekerci, MD; ${ }^{*}$ Cem Akbal, MD; ${ }^{*}$ Tarik Emre Sener, MD; ${ }^{*}$ Ahmet Sahan, MD; Bahadir Sahin, MD; \\ Feyyaz Baltacioglu, MD; ${ }^{\dagger}$ Ferruh Simsek, MD*
}

*Marmara University, School of Medicine, Department of Urology, Turkey; ${ }^{\dagger}$ Marmara University, School of Medicine, Department of Radiology, Turkey

Cite as: Can Urol Assoc J 2015;9(7-8):E562-4. http://dx.doi.org/10.5489/cuaj.2952 Published online August 10, 2015.

\section{Abstract}

Priapism in pediatric patients is a rare entity. We present an 8-yearold boy with known cerebral palsy. He came to the emergency department with sustained painful erection for 12 hours. Physical examination showed rigid penis. Blood count and biochemical analysis were normal. Although penile Doppler ultrasound revealed normal arterial and venous flow, cavernosal blood gas was hypoxic. A total of $50 \mathrm{~mL}$ of dark blood was aspirated, and $2 \mathrm{~mL}$ of $0.001 \%$ adrenalin solution was applied to both corpus cavernosum, twice within 20 minutes, which eventually did not achieve detumescence. A distal Winter shunt was performed at the end of which the penis was semi-flaccid. By the 18th hour of surgery, the penis re-gained painful erection status, so an Al-Ghorab shunt was performed. After the Al-Ghorab shunt, the penis was still in the semi-flaccid state. The next day, an angiography was performed and an arteriovenous fistula was discovered and treated by embolization. The flaccid state was achieved and the patient was discharged the day after the embolization.

\section{Introduction}

Priapism in pediatric patients is rare. We report a case of an 8-year-old boy with resistant priapism.

\section{Case report}

The patient is an 8-year-old boy with mild cerebral palsy, for which he is not under any neurological medication. His cognitive status is almost normal and he is under conservative follow-up. He presented to the emergency department with sustained painful erection for 12 hours. On initial workup, no abnormality was discovered in his blood samples. Although penile Doppler ultrasound revealed normal arterial and venous flow, cavernosal blood gas was hypoxic
(pO2 <30 mmHg, pCO2 >60 mmHg, pH <7.25). He was immediately taken to the operating room to decompress the corpus cavernosum. A total of $50 \mathrm{~mL}$ of venous blood was aspirated from both of the corpus cavernosum, but the penis did not reach a flaccid state.

Phenylephrine is not commercially available in Turkey, so we applied $2 \mathrm{~mL}$ of $0.001 \%$ adrenaline solution to both corpus cavernosum twice within 20 minutes, which eventually did not achieve detumescence. A distal Winter shunt operation was performed, at the end of which the penis was semi-flaccid. The blood gas values aspirated from the penile shaft during the surgery revealed venous ischemic priapism. The next day, pediatric hematologists ruled out any hematological disorder, including sickle cell anemia. By the 18th hour of surgery, the penis regained its painful erection status, so we decided to perform an Al-Ghorab shunt. After the Al-Ghorab shunt, which took place at the 20th hour of the first surgery, the penis was still in the semiflaccid state. The next day, the interventional radiologist performed an angiography and an arteriovenous fistula was discovered and treated by embolization with a microplex 10 coil (Fig. 1, Fig. 2). The flaccid state was achieved and patient was discharged the day after AVM embolization. One week and 3 months later, the patient came to the outpatient clinic for follow-up; he was in full recovery.

\section{Discussion}

Priapism is a rare condition in childhood defined as the prolonged state of penile erection lasting more than 4 hours. The most common presentation is the ischemic priapism, the other types are stuttering priapism that is recurrent and self-limiting and the nonischemic priapism that is rare and usually results after trauma. ${ }^{1}$ The most common causes are sickle cell disease (65\%), leukemia $(10 \%)$, trauma $(10 \%)$, idiopathic (10\%), and pharmacologic (5\%). Treatment should be conducted urgently as it may prevent permanent structural damage and may provide improved prognosis for potency. ${ }^{2}$ 


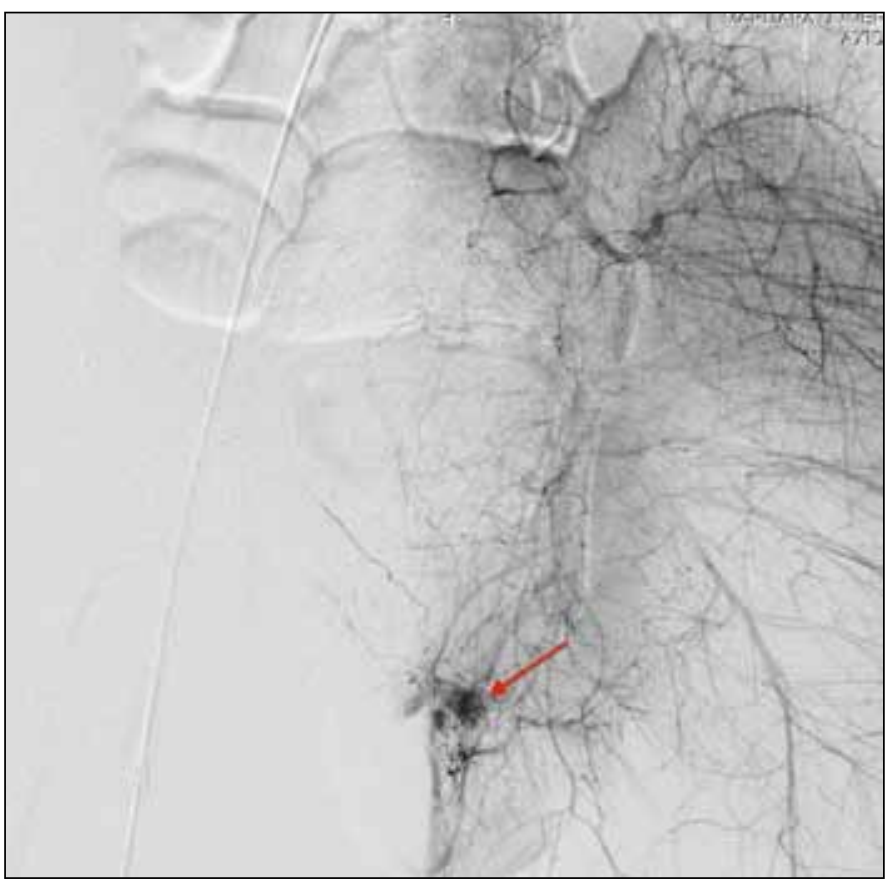

Fig. 1. Penile angiography revealing an arterio-venous (AV) fistula. (red arrow marks the AV fistula).

First-line treatment includes aspiration and irrigation of the cavernosal bodies with saline solution to promote recirculation of the blood flow and to prevent compartmentlike syndrome. ${ }^{3}$ Aspiration and irrigation of the cavernosal bodies can cause infection, penile abscess, and vascular thrombosis. ${ }^{4,5}$ Another option is the intracavernosal injection of phenylephrine or adrenaline. These agents may cause cardiovascular side effects, so it is very important to closely monitor the patient. Phenylephrine is the drug of choice due to high selectivity of alpha-1-adrenergic receptor without concomitant beta-mimetic effects. ${ }^{6}$ Adrenaline is also used with $50 \%$ success rates with single injection, which may extend up to $95 \%$ with repeated injections. ${ }^{7}$

Second-line treatment includes shunt surgery, which should only be considered in cases of first-line failure. The shunt surgeries provide an opening in the tunica albuginea of the cavernosal body and corpus spongiosum or a vein for blood drainage. ${ }^{8}$ These shunt surgeries may be grouped as percutaneous and open distal shunts, open proximal shunts and vein anastomoses. ${ }^{9}$ Distal Winter shunt is one of the least successful shunt operations, but it is relatively easy to perform with no sequel after the surgery. ${ }^{10} \mathrm{Al}$-Ghorab's and Burnett's shunts are open distal shunts, which are more efficient than percutaneous shunts. ${ }^{11}$ Sacher's and Quackle's shunts are open proximal shunts, which should be considered after distal shunts and which can be performed with higher rates of complications. ${ }^{8}$ Selective arterial embolization is usually preserved for arterial priapism. Success rates $(89 \%)$ are reported in small studies. ${ }^{4}$ Recurrence rates are

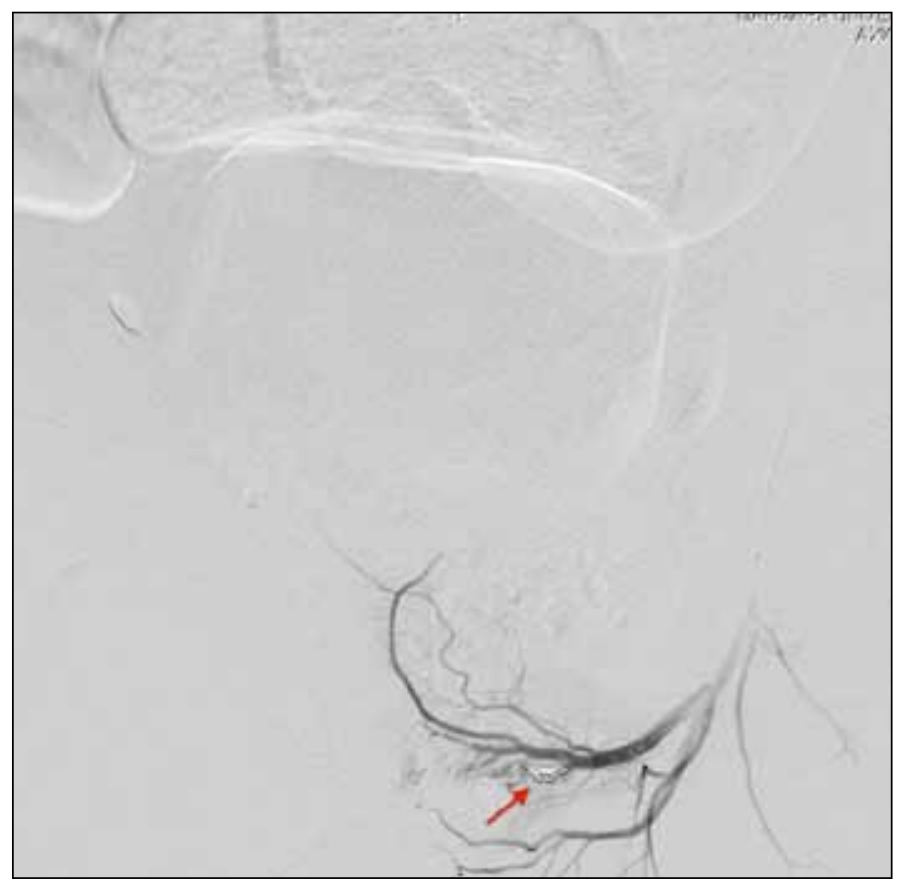

Fig. 2. Penile angiography after embolization of the arterio-venous fistula (red arrow marks the embolization material).

low $(7 \%-27 \%) .{ }^{12-14}$ Embolization in children, although successful, is technically challenging and requires treatment in a specialist pediatric vascular radiology department. ${ }^{15,16}$

We report an interesting case of priapism, which was resistant to each treatment applied for the patient. The initial clinical presentation of our patient was the ischemic priapism, which was confirmed with routine blood work including complete blood count, biochemical analysis and hypoxic penile blood gas analysis. Cavernous blood gas values for ischemic priapism typically show a $\mathrm{pO}_{2}$ of $<30 \mathrm{mmHg}$, $\mathrm{pCO}_{2}$ of $>60 \mathrm{mmHg}$, and $\mathrm{pH}<7.25$. Conversely, cavernous blood gas values for non-ischemic priapism are $\mathrm{pO} 2$ $>90 \mathrm{mmHg}$, pCO2 <40 mmHg, and pH 7.40, consistent with normal arterial blood at room temperature. ${ }^{17,18}$ However, we do not have any information about the specific cut off value of $\mathrm{O}_{2}$ saturation for children.

This presentation usually responds to common interventions, such as blood aspiration from penile shaft and saline irrigation, followed by intracavernosal adrenaline injection. However, our patient did not benefit from these commonly administered treatments and we performed 2 distal shunt operations, which did not result in a full flaccid state. Afterwards, further evaluation led to the discovery of an arterio-venous fistula, which is a rare entity. This was treated by a successful angio-embolization and led to full flaccid state. This patient had ischemic priapism at the beginning then this conversion might have been caused by aspiration and iatrogenic injury to one of the branches of the cavernosal artery, which eventually caused the AVM. This conversion 
Akbal et al.

from a low-flow state of priapism to a high-flow state is very rare; to our knowledge, this is the third reported case. ${ }^{19,20}$

This case shows us the importance of re-evaluation in treatment-resistant priapism. Especially in pediatric patients, detailed questioning may reveal the underlying cause, such as ingestion of pills. In children, there are cases of accidentally ingested phosphodiesterase- 5 inhibitor drugs. In children with neurological disorders, the medications that a child takes should be questioned. These issues were not true in our patient. ${ }^{21,22}$ However, we discovered that our patient had a traumatic incident a week before the initial presentation, which revealed the importance of traumatic events in the cause of priapism. ${ }^{23}$

\section{Conclusion}

Priapism in the pediatric population is a urological emergency, which should be evaluated thoroughly and carefully, and subsequently, should be treated with great caution to achieve a healthy flaccid state of the penis and to avoid any late-term complications. If confirmed ischemic priapism in children does not improve promptly with aspiration and shunt surgeries, an angiography should be done without delay.

Competing interests: The authors all declare no competing financial or personal interests.

This paper has been peer-reviewed.

\section{References}

1. Broderick, GA, et al. Priapism: pathogenesis, epidemiology, and management. J Sex Med 2010;7:476500. http://dx.doi.org/10.1111/i.1743-6109.2009.01625.x

2. Donaldson, JF, RW Rees, and HA, Steinbrecher. Priapism in children: A comprehensive review and clinical guideline. J Pediatr Urol 2014;10:11-24. http://dx.doi.org/10.1016/i.jpurol.2013.07.024

3. Montague, DK, et al. American Urological Association guideline on the management of priapism. J Urol 2003;170:1318-24. http://dx.doi.org/10.1097/01.ju.0000087608.07371.ca

4. Pryor, J, et al. Priapism. J Sex Med 2004;1:116-20. http://dx.doi.org/10.1111/i.17436109.2004.10117.x
5. Rochat, MC. Priapism: A review. Theriogenology 2001;56:713-22. http://dx.doi.org/10.1016/50093$691 \times(01) 00622-7$

6. Muneer, $A$, et al. Investigating the effects of high-dose phenylephrine in the management of prolonged ischaemic priapism. J Sex Med 2008;5:2152-9. http://dx.doi.org/10.1111/j.1743-6109.2008.00862.x

7. Keskin, D, et al. Intracavernosal adrenalin injection in priapism. Int I Impot Res 2000;12:312-4. http:// dx.doi.org/10.1038/si.jiir.3900539

8. Burnett, AL. Surgical management of ischemic priapism. J Sex Med 2012;9: 114-20. http://dx.doi. org/10.1111/i.1743-6109.2011.02446.x

9. Salonia, A, et al. European Association of Urology guidelines on priapism. Eur Urol 2014;65:480-9. http://dx.doi.org/10.1016/i.eururo.2013.11.008

10. Nixon, RG, $0^{\prime}$ Connor, JL, Milam, DF. Efficacy of shunt surgery for refractory low flow priapism: A report on the incidence of failed detumescence and erectile dysfunction. J Urol 2003;170:883-6. http://dx.doi. org/10.1097/01.ju.0000081291.37860.05

11. Lue, TF, Pescatori, ES. Distal cavernosum-glans shunts for ischemic priapism. J Sex Med 2006;3:749-52. http://dx.doi.org/10.1111/j.1743-6109.2006.00281.x

12. Numan, $F$, et al. Posttraumatic nonischemic priapism treated with autologous blood clot embolization. J Sex Med 2008;5:173-9.

13. Savoca, $G$, et al. Sexual function after highly selective embolization of cavernous artery in patients with high flow priapism: Long-term followup. J Urol 2004;172:644-7. http://dx.doi.org/10.1097/01. ju.0000132494.44596.33

14. Kim, KR, et al. Treatment of high-flow priapism with superselective transcatheter embolization in 27 patients: A multicenter study. J Vasc Interv Radiol 2007;18:1222-6. http://dx.doi.org/10.1016/j. jivi.2007.06.030

15. Miller, $\mathrm{SF}$, et al. Posttraumatic arterial priapism in children: management with embolization. Radiology 1995;196:59-62. http://dx.doi.org/10.1148/radiology.196.1.7784590

16. Cantasdemir, $M$, et al. Posttraumatic high-flow priapism in children treated with autologous blood clot embolization: Long-term results and review of the literature. Pediatr Radiol 2011;41:627-32. http:// dx.doi.org/10.1007/s00247-010-1912-3

17. Song, Y, Song, YS. Diagnosis and treatment of priapism: A report of 15 cases. Zhonghua Nan Ke Xue 2008;14:829-31.

18. Llorente, $C$, et al. Value of cavernous gasometry in the physiopathologic diagnosis and treatment of priapism. Actas Urol Esp 1990;14:444-5.

19. Canguven, 0 , Tarhan, F. Re: Conversion of low-flow to high-flow priapism: A case report and review. J Sex Med 2013;10:617. http://dx.doi.org/10.1111/i.1743-6109.2012.02832.x

20. Lutz, A, Lacour, S, Hellstrom, W. Conversion of low-flow to high-flow priapism: A case report and review (CME). J Sex Med 2012;9:951-4;quiz 955. http://dx.doi.org/10.1111/j.1743-6109.2012.02692.x

21. Cantrell, FL. Sildenafil citrate ingestion in a pediatric patient. Pediatr Emerg Care 2004;20:314-5. http:// dx.doi.org/10.1097/01.pec.0000125660.50937.b5

22. Wills, BK, et al. Sildenafil citrate ingestion and prolonged priapism and tachycardia in a pediatric patient. Clin Toxicol (Phila) 2007;45:798-800. http://dx.doi.org/10.1080/15563650701664483

23. Hosokawa, Y, et al. Post-traumatic high-flow priapism: A case report. Hinyokika Kiyo 2004;50:249-51.

Correspondence: Dr. Cem Akbal, Marmara University, School of Medicine, Department of Urology, Turkey; cakbal@gmail.com 